\title{
Caenimonas koreensis gen. nov., sp. nov., isolated from activated sludge
}

\author{
Seung Hyun Ryu, ${ }^{1} \dagger$ Dae Sung Lee, ${ }^{2}$ † Minjeong Park, ${ }^{1}$ Qian Wang, ${ }^{1}$ \\ Ho Hee Jang, ${ }^{1}$ Woojun Park ${ }^{3}$ and Che Ok Jeon ${ }^{1,4}$ \\ ${ }^{1}$ Division of Applied Life Science (BK21 Program), EB-NCRC, PMBBRC, Gyeongsang National \\ University, Jinju 660-701, Republic of Korea \\ ${ }^{2}$ Department of Environmental Engineering, Kyungpook National University, Daegu 702-701, \\ Republic of Korea \\ ${ }^{3}$ Division of Environmental Science and Ecological Engineering, Korea University, Seoul 136-701, \\ Republic of Korea \\ ${ }^{4}$ Department of Life Science, Chung-Ang University, Seoul 156-756, Republic of Korea
}

Correspondence

Che Ok Jeon

cojeon@gnu.ac.kr

\begin{abstract}
A Gram-negative, rod-shaped bacterium, designated strain $\mathrm{EMB} 3 \mathrm{O}^{\top}$, was isolated from activated sludge performing enhanced biological phosphorus removal in a sequencing batch reactor. The isolate was strictly aerobic and non-motile. Growth was observed between 10 and $35{ }^{\circ} \mathrm{C}$ (optimum $30{ }^{\circ} \mathrm{C}$ ) and between $\mathrm{pH} 6.0$ and 9.0 (optimum pH 7.0-8.0). The predominant cellular fatty acids of strain $E M B 320^{\top}$ were $\mathrm{C}_{16: 0,}, \mathrm{C}_{18: 1} \omega 7 \mathrm{c}$ and summed feature 3 $\left(\mathrm{C}_{16: 1} \omega 7 \mathrm{c}\right.$ and/or iso- $\left.\mathrm{C}_{15: 0} 2-\mathrm{OH}\right)$. The major polar lipids were phosphatidylethanolamine, phosphatidylglycerol and diphosphatidylglycerol. Strain $\mathrm{EMB} 320^{\top}$ contained ubiquinone-8 (Q-8) as the major respiratory quinone system and 2-hydroxyputrescine and putrescine as the major polyamines, which suggests that it belongs to the Betaproteobacteria. The $\mathrm{G}+\mathrm{C}$ content of the genomic DNA was 62.7 mol\%. Comparative 16S rRNA gene sequence analysis showed that strain $\mathrm{EMB} 320^{\top}$ formed a phyletic lineage distinct from other genera within the family Comamonadaceae. On the basis of chemotaxonomic data and molecular properties, strain EMB320 ${ }^{\top}$ represents a novel genus and species within the family Comamonadaceae, for which the name Caenimonas koreensis sp. nov. is proposed. The type strain of Caenimonas koreensis is $\operatorname{EMB} 320^{\top}\left(=\right.$ KCTC $12616^{\top}=$ DSM $\left.17982^{\top}\right)$.
\end{abstract}

The family Comamonadaceae belonging to the Betaproteobacteria (Stackebrandt et al., 1988) was described to include the genera Comamonas, Acidovorax, Hydrogenophaga, Xylophilus and Variovorax (described to include the former Alcaligenes paradoxus), as well as phylogenetically misnamed [Aquaspirillum] and phytopathogenic [Pseudomonas] species (Willems et al., 1991). Since then, several species have been transferred to other genera or reclassified as members of novel genera by the application of molecular and improved phenotypic approaches (Willems et al., 1992; Hiraishi, 1994; Wen et al., 1999;

Abbreviation: EBPR, enhanced biological phosphate removal.

†These authors contributed equally to this work.

The GenBank/EMBL/DDBJ accession number for the 16S rRNA gene sequence of strain EMB320 ${ }^{\top}$ is DQ349098.

A transmission electron micrograph of cells and results of TLC of polar lipids of strain EMB320 ${ }^{\top}$ and maximum-likelihood and maximumparsimony $16 \mathrm{~S}$ rRNA gene sequence-based phylogenetic trees are available as supplementary material with the online version of this paper.
Ding \& Yokota, 2004), and new genera such as Rhodoferax, Xenophilus, Polaromonas, Alicycliphilus and Ramlibacter have been added to the family (Hiraishi et al., 1991; Irgens et al., 1996; Blümel et al., 2001; Heulin et al., 2003; Mechichi et al., 2003).

Activated sludge processes with cyclic changes of anaerobic and aerobic conditions have been used to remove phosphate from wastewater and are becoming more important for reducing eutrophication of lakes. An understanding of the microbial community responsible for phosphorus removal is a prerequisite for understanding the mechanism of enhanced biological phosphorus removal (EBPR). Therefore, efforts to isolate bacteria performing EBPR have been made in our laboratory ( $\mathrm{Lu}$ et al., 2006) and here we describe the taxonomic characterization of a strain isolated from activated sludge that represents a novel genus belonging to the family Comamonadaceae.

Strain $\mathrm{EMB}_{32} 0^{\mathrm{T}}$ was isolated from activated sludge performing EBPR in a lab-scale sequencing batch reactor (SBR). Sodium acetate was supplied as a sole carbon source 
and the operation of the SBR has been described elsewhere (Jeon et al., 2003). A sludge sample was diluted serially with $1 \%(\mathrm{w} / \mathrm{v})$ saline solution and spread on R2A agar (Difco) and incubated at $20{ }^{\circ} \mathrm{C}$ for 7 days for isolation. Subcultivation was done on R2A agar at $30{ }^{\circ} \mathrm{C}$ for 5 days. The type strains of some other related taxa, Rhodoferax ferrireducens DSM $15236^{\mathrm{T}}$, Curvibacter delicatus DSM $11558^{\mathrm{T}}$, Xylophilus ampelinus DSM $7250^{\mathrm{T}}$, Ramlibacter tataouinensis DSM $14655^{\mathrm{T}}$, Variovorax paradoxus KCTC $12459^{\mathrm{T}}$ and Polaromonas naphthalenivorans $\mathrm{CJ} 2^{\mathrm{T}}$, were used as reference strains for biochemical tests.

Gram staining was performed using the bioMérieux Gram stain kit according to the manufacturer's instructions. Cell morphology and motility were studied using phase-contrast microscopy and transmission electron microscopy (JEM1010; JEOL) as described by Jeon et al. (2005). Physiological characteristics of strain $\mathrm{EMB} 320^{\mathrm{T}}$ were examined by growing the isolate on $\mathrm{R} 2 \mathrm{~A}$ medium at different temperatures and $\mathrm{pH}$. $\mathrm{R} 2 \mathrm{~A}$ medium was prepared with different $\mathrm{pH}$ values as described previously (Gomori, 1955). Oxidase activity was tested by oxidation of $1 \%(w / v)$ tetramethyl- $p$ phenylenediamine (Merck) and catalase activity was evaluated by production of oxygen bubbles in $3 \%(\mathrm{v} / \mathrm{v})$ aqueous hydrogen peroxide solution. The hydrolysis of compounds was assessed on R2A agar after 5 days of incubation according to methods described previously (Lányí, 1987; Smibert \& Krieg, 1994). Nitrate reduction was performed according to the method of Lányí (1987) and acid production from carbohydrates was tested as described by Leifson (1963). Utilization of thiosulfate was tested in R2A broth supplemented with $10 \mathrm{mM} \mathrm{Na} \mathrm{S}_{2} \mathrm{O}_{3} \cdot 5 \mathrm{H}_{2} \mathrm{O}$ as described by Spring et al. (2004) and the concentration of sulfate, the end product of thiosulfate oxidation, was quantified in spent R2A medium using anion chromatography (Dionex; ICS-1000). Carbon source utilization was tested in mineral medium as described by Kämpfer et al. (1991). The utilization of D-fructose, D-glucose, glycerol, malonate, D-mannitol, maleate and D- and L-tryptophan was tested. Chemolithoautotrophic growth of strain EMB320 ${ }^{\mathrm{T}}$ with hydrogen gas was tested on medium 81 (Deutsche Sammlung von Mikroorganismen und Zellkulturen, Braunschweig, Germany) agar under the conditions described by Malik \& Schlegel (1981). More enzyme activities and biochemical features were determined by using API kits (API ZYM, API 20E and API 20NE) as recommended by the manufacturer (bioMérieux).

Strain $\mathrm{EMB} 320^{\mathrm{T}}$ on R2A agar formed white, glistening, translucent, slightly sticky and slightly raised circular colonies when grown at $30{ }^{\circ} \mathrm{C}$ for 5 days. Growth was observed at temperatures between 10 and $35{ }^{\circ} \mathrm{C}$, with an optimum growth temperature of $30{ }^{\circ} \mathrm{C}$. The strain grew at the range of $\mathrm{pH}$ 6.0-9.0 with optimum growth between $\mathrm{pH} 7.0$ and 8.0. Cells of the isolate were non-motile rods (0.4-0.6 $\mu \mathrm{m}$ wide and $0.8-2.0 \mu \mathrm{m}$ long) without flagella (Supplementary Fig. S1, available in IJSEM Online), Gramnegative and oxidase- and catalase-positive. The isolate did not grow on R2A agar with the removal of yeast extract and peptone under aerobic conditions, but it grew well following the addition of vitamin mixture (Wolin et al., 1963), meaning that it was possible to replace these complex nutrients (yeast extract and peptone) with vitamins. Anaerobic growth was not observed after incubation for 10 days at $30{ }^{\circ} \mathrm{C}$ on $\mathrm{R} 2 \mathrm{~A}$ agar or on R2A agar containing $10 \mathrm{mM}$ nitrate.

Analysis of fatty acid methyl esters was performed according to the instructions of the Microbial Identification System (MIDI Inc.) after cultivation for 5 days on R2A agar at $30{ }^{\circ} \mathrm{C}$. Analyses of polar lipids and isoprenoid quinones were carried out using the methods described by Komagata \& Suzuki (1987). Polyamines were analysed using an HPLC (Shimadzu LC-10A) equipped with a fluorescence detector (Shimadzu RF-10AXL) and a reversed-phase column [Akzo Nobel; Kromasil ODS $(250 \times 4.6 \mathrm{~mm})]$ as described previously (Busse \& Auling, 1988; Busse et al., 1997). The DNA $\mathrm{G}+\mathrm{C}$ content of strain EMB $320^{\mathrm{T}}$ was determined using an HPLC fitted with a reversed-phase column [GROM; GROMSIL 100 ODS-2FE $(250 \times 4.6 \mathrm{~mm})]$ according to the method of Tamaoka \& Komagata (1984). The major respiratory lipoquinone of strain EMB320 ${ }^{\mathrm{T}}$ was ubiquinone-8 (Q-8). The cellular fatty acids of the strain were summed feature 3 $\left(\mathrm{C}_{16: 1} \omega 7 c\right.$ and/or iso- $\left.\mathrm{C}_{15: 0} 2-\mathrm{OH} ; 41.8 \%\right), \mathrm{C}_{16: 0}(25.9 \%)$, $\mathrm{C}_{18: 1} \omega 7 c(15.8 \%), \mathrm{C}_{18: 1} \omega 7 c 11$-methyl (4.9\%), $\mathrm{C}_{10: 0} 3-\mathrm{OH}$ (3.5\%), $\mathrm{C}_{17: 0}(2.0 \%), \mathrm{C}_{15: 0}(1.9 \%), \mathrm{C}_{14: 0}(1.5 \%), \mathrm{C}_{12: 0}$ $(0.9 \%), \mathrm{C}_{18: 0}(0.9 \%)$ and summed feature $7\left(\mathrm{C}_{19: 0}\right.$ cyclo $\omega 10 c$ and/or $\left.\mathrm{C}_{19: 1} \omega 6 \mathrm{c} ; 0.9 \%\right)$. The strain exhibited a polar lipid profile consisting of major lipid phosphatidylethanolamine, moderate amounts of phosphatidylglycerol and diphosphatidylglycerol and a small amount of an unknown amino group-containing lipid (Supplementary Fig. S2). The presence of phosphatidylethanolamine, phosphatidylglycerol and diphosphatidylglycerol and the lack of glycolipids were in agreement with the polar lipid characteristics reported for the related species Polaromonas naphthalenivorans, Polaromonas aquatica and Xenophilus azovorans. Strain EMB $320^{T}$ was characterized by the presence of the betaproteobacteria-specific diamine 2-hydroxyputrescine [55 $\mu \mathrm{mol}(\mathrm{g} \text { dry weight })^{-1}$ ] and putrescine [16 $\mu \mathrm{mol}(\mathrm{g}$ dry weight $)^{-1}$. The content of 2-hydroxyputrescine was a little higher than in any other species analysed so far, such as $P$. naphthalenivorans and P. aquatica (Busse \& Auling, 1988; Kämpfer et al., 2006). Other polyamines were only detected in trace amounts. The $\mathrm{G}+\mathrm{C}$ content of the genomic DNA of strain $\mathrm{EMB} 320^{\mathrm{T}}$ was $62.7 \mathrm{~mol} \%$. The phenotypic characteristics of strain $\mathrm{EMB} 320^{\mathrm{T}}$ are presented in the genus and species descriptions and are compared with those of closely related taxa in Table 1.

Sequencing and assembly of the 16S rRNA gene were carried out as described previously (Lane, 1991). The resultant 16S rRNA gene sequence (1457 nucleotides) of strain $\mathrm{EMB} 320^{\mathrm{T}}$ was compared with available $16 \mathrm{~S}$ rRNA gene sequences from GenBank using the BLAST program (http://www.ncbi.nlm.nih.gov/BLAST/) to determine an approximate phylogenetic affiliation and was aligned with closely related members using the CLUSTAL $\mathrm{w}$ software 
Table 1. Characteristics of strain $\mathrm{EMB} 2 \mathrm{O}^{\top}$ (Caenimonas koreensis gen. nov., sp. nov.) and related members of the family Comamonadaceae

Data for reference genera were taken from Heulin et al. (2003) (Ramlibacter), Willems et al. (1991) and Yoon et al. (2006) (Variovorax), Hiraishi et al. (1991) and Finneran et al. (2003) (Rhodoferax), Ding \& Yokota (2004) (Curvibacter), Irgens et al. (1996), Jeon et al. (2004), Kämpfer et al. (2006) and Sizova \& Panikov (2007) (Polaromonas) and Willems et al. (1987) (Xylophilus) unless indicated. NA, No data available; RQ, rhodoquinone.

\begin{tabular}{|c|c|c|c|c|c|c|c|}
\hline Characteristic & Strain EMB320 ${ }^{\mathrm{T}}$ & Ramlibacter & Variovorax & Rhodoferax & Curvibacter & Polaromonas & Xylophilus \\
\hline Morphology & Rods & $\begin{array}{l}\text { Rods or } \\
\text { cysts }\end{array}$ & Rods & Curved rods & Curved rods & Rods or cocci & Rods \\
\hline Flagella & None & None & Peritrichous & One polar & None or polar & None or polar & One polar \\
\hline Oxidase $^{\star}$ & + & + & + & + & + & + & - \\
\hline Urease $^{\star}$ & - & - & + & - & - & - & + \\
\hline Nitrate reduction* & + & + & + & + & - & + & - \\
\hline Pigments on $\mathrm{R} 2 \mathrm{~A}^{*}$ & - & + & + & - & - & - & + \\
\hline Growth at $4{ }^{\circ} \mathrm{C}^{*}$ & - & - & - & - & - & + & - \\
\hline $\begin{array}{l}\text { Chemolithotrophic growth } \\
\text { with } \mathrm{H}_{2}{ }^{*}\end{array}$ & - & - & + & - & + & + & - \\
\hline Glucose fermentation ${ }^{\star}$ & - & - & - & + & - & - & - \\
\hline$\beta$-Galactosidase ${ }^{\star}$ & - & - & - & + & + & - & - \\
\hline \multicolumn{8}{|l|}{ Hydrolysis of: ${ }^{*}$} \\
\hline Aesculin & - & + & - & + & - & + & - \\
\hline Gelatin & + & - & - & - & - & + & - \\
\hline \multicolumn{8}{|l|}{ Assimilation of: ${ }^{*}$} \\
\hline $\begin{array}{l}\text { D-Glucose, L-arabinose, } \\
\text { D-mannose, D-mannitol }\end{array}$ & - & - & + & - & - & - & - \\
\hline Gluconate, adipic acid & - & - & + & - & + & - & - \\
\hline Quinone(s) & Q-8 & $\mathrm{NA}$ & Q-8 & Q-8, RQ-8 & Q-8 & Q-8 & Q-8, RQ-8 \\
\hline Major cellular fatty acids & $\begin{array}{c}16: 0,16: 0 \omega 7 c l \\
\text { iso-15:0 } 2-\mathrm{OH} \\
18: 1 \omega 7 c\end{array}$ & $\mathrm{NA}$ & $\begin{array}{c}16: 0,16: 1 \\
18: 1\end{array}$ & $16: 0,16: 1$ & $16: 0,16: 1,18: 1$ & $\begin{array}{c}16: 0,16: 1 \omega 7 c l \\
16: 1 \omega 6 c, 18: 1 \omega 7 c \\
\quad 17: 0 \text { cyclo } \dagger\end{array}$ & NA \\
\hline Major 3-OH acid & $10: 0$ & NA & $10: 0$ & $8: 0$ & $8: 0$ & $10: 0 \ddagger$ & NA \\
\hline DNA G $+C$ content $(\mathrm{mol} \%)$ & 62.7 & $67-70$ & $66-69$ & $59-62$ & $62-66$ & $52-63$ & $68-69$ \\
\hline
\end{tabular}

${ }^{\star}$ Data obtained in this study for Ramlibacter tataouinensis $\mathrm{TTB} 310^{\mathrm{T}}$, Variovorax paradoxus IAM $12373^{\mathrm{T}}$, Rhodoferax ferrireducens $\mathrm{T} 118^{\mathrm{T}}$, Curvibacter delicatus LMG $4328^{\mathrm{T}}$, Polaromonas naphthalenivorans $\mathrm{CJ} 2^{\mathrm{T}}$ and Xylophilus ampelinus DSM $7250^{\mathrm{T}}$. All of these strains and strain EMB320 ${ }^{\mathrm{T}}$ were negative for indole and arginine dihydrolase production and assimilation of $\mathrm{N}$-acetylglucosamine, maltose, capric acid, malic acid, trisodium citrate and phenylacetic acid.

$\dagger \mathrm{C}_{17: 0}$ cyclo is present only in P. aquatica CCUG $39402^{\mathrm{T}}(37.3 \%)$ and P. naphthalenivorans $\mathrm{CJ} 2^{\mathrm{T}}$ (7.2\%) (Jeon et al., 2004; Sizova \& Panikov, 2007).

$\ddagger$ Only P. hydrogenivorans DSM $17735^{\mathrm{T}}$ and P. naphthalenivorans $\mathrm{CJ} 2^{\mathrm{T}}$ contain $\mathrm{C}_{10: 0} 3-\mathrm{OH}$ as the major hydroxylated fatty acid (Jeon et al., 2004 ; Sizova \& Panikov, 2007).

(Thompson et al., 1994). Phylogenetic trees were constructed using three different methods, the neighbour-joining (NJ), maximum-likelihood (ML) and maximum-parsimony (MP) algorithms, which are available in the PHYLIP software, version 3.6 (Felsenstein, 2002). Sequence similarity values were computed using Similarity Matrix version 1.1 (Ribosomal Database Project II; http://35.8.164.52/html/) (Cole et al., 2003). A bootstrap analysis was performed according to the algorithm of Kimura's two-parameter model (Kimura, 1980) of the NJ method in the PHYLIP package. Comparative analysis of $16 \mathrm{~S}$ rRNA gene sequences showed that the isolate was closely related to Variovorax paradoxus IAM $12373^{\mathrm{T}}$, Curvibacter delicatus LMG $4328^{\mathrm{T}}$, Curvibacter gracilis $7-1^{\mathrm{T}}$, Xylophilus ampelinus DSM $7250^{\mathrm{T}}$ and Ramlibacter tataouinensis TTB3 $10^{\mathrm{T}}$, with similarities of
96.8, 96.8, 96.8, 96.7 and $96.0 \%$, respectively. However, the phylogenetic analysis indicated that strain EMB320 ${ }^{\mathrm{T}}$ formed a phyletic lineage with the genera Curvibacter, Rhodoferax and Polaromonas within the family Comamonadaceae with a low bootstrap value $(44 \%)$, meaning that the phylogenetic topology is not stable (Fig. 1). Additional phylogenetic analyses also showed that the phylogenetic topologies varied remarkably by the addition or removal of just one species. The topologies of phylogenetic trees built using the ML and MP algorithms also supported the notion that there is no genus group that shows a clear phylogenetic relationship with strain $\mathrm{EMB}_{32} 0^{\mathrm{T}}$ in the family Comamonadaceae (Supplementary Fig. S3), which was confirmed using the Ribosomal Database Project Classifier program (Wang et al., 2007). 


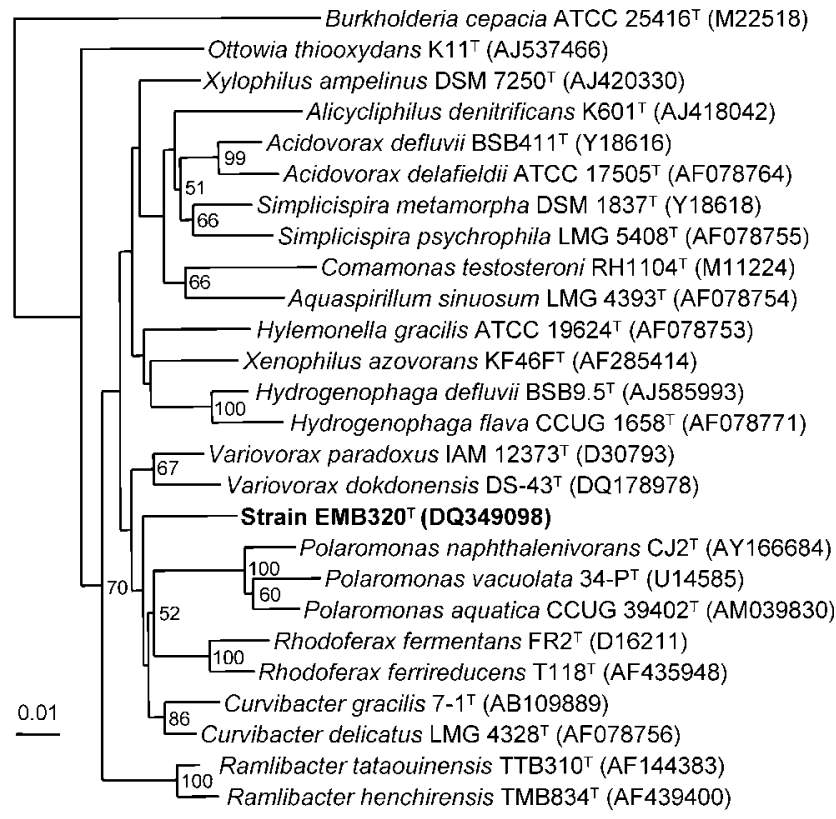

Fig. 1. Neighbour-joining tree showing phylogenetic relationships based on 16S rRNA gene sequences of strain $\mathrm{EMB} 30^{\top}$ and related taxa. Bootstrap values are shown as percentages of 1000 replicates when greater than $50 \%$. Burkholderia cepacia ATCC $25416^{\top}$ was used as an outgroup. Bar, 0.01 changes per nucleotide position.

\section{Description of Caenimonas gen. nov.}

Caenimonas (Cae'ni.mo' nas. L. n. caenum mud, sludge; N.L. fem. n. from Gr. fem. n. monas a unit, monad; N.L. fem. n. Caenimonas monad isolated from sludge).

Cells are Gram-negative, strictly aerobic, non-motile rods, $0.4-0.6 \mu \mathrm{m}$ wide and $0.8-2.0 \mu \mathrm{m}$ long, at $30^{\circ} \mathrm{C}$ on $\mathrm{R} 2 \mathrm{~A}$ agar. Catalase- and oxidase-positive. Nitrate is reduced to nitrite and thiosulfate is oxidized to sulfate. No aerobic chemoautotrophic growth with hydrogen as substrate. Contain phosphatidylethanolamine, phosphatidylglycerol and diphosphatidylglycerol and an unknown amino groupcontaining lipid as polar lipids. The major isoprenoid quinone is ubiquinone-8 (Q-8). Major polyamines are 2hydroxyputrescine and putrescine. The major fatty acids are $\mathrm{C}_{16: 1} \omega 7 c$ and/or iso- $\mathrm{C}_{15: 0} 2-\mathrm{OH}, \mathrm{C}_{16: 0}$ and $\mathrm{C}_{18: 1} \omega 7 c$. The DNA $\mathrm{G}+\mathrm{C}$ content of the type strain of the type species is $62.7 \mathrm{~mol} \%$ (HPLC). Phylogenetically, the genus belongs to the family Comamonadaceae. The type species is Caenimonas koreensis.

\section{Description of Caenimonas koreensis sp. nov.}

Caenimonas koreensis (ko.re.en'sis. N.L. fem. adj. koreensis pertaining to Korea, where the type strain was isolated).

Displays the following properties in addition to those given in the genus description. Colonies are white, glistening, translucent, slightly sticky, raised and circular on R2A agar. Growth occurs optimally at $30{ }^{\circ} \mathrm{C}$ and $\mathrm{pH} 7.0-8.0$. Negative for the production of indole, $\mathrm{H}_{2} \mathrm{~S}$ and acetoin and negative for citrate utilization (API 20E). Hydrolyses urea, gelatin and Tween 20 but does not hydrolyse casein, Tween 80, tyrosine, aesculin or starch. Acid is produced from raffinose, myo-inositol, D-lactose, L-arabinose and Dfructose, but not from D-glucose, sorbitol, sucrose, rhamnose, amygdalin, melibiose, D-galactose, D-mannose, D-mannitol, arbutin or salicin. Negative for assimilation of D-glucose, D-mannose, D-mannitol, $\mathrm{N}$-acetylglucosamine, maltose, L-arabinose, potassium gluconate, capric acid, adipic acid, malic acid, trisodium citrate and phenylacetic acid (API 20NE). Utilizes D-fructose, D-glucose, malonate and maleate as sole carbon sources, but does not utilize glycerol, D-mannitol or D- or L-tryptophan. Produces alkaline phosphatase, leucine arylamidase and urease, but not lipase (C14), cystine arylamidase, trypsin, $\alpha$-chymotrypsin, $\alpha$-galactosidase, $\beta$-galactosidase, $\beta$-glucuronidase, $\alpha$-glucosidase, $\beta$-glucosidase, $N$-acetyl- $\beta$-glucosaminidase, $\alpha$-mannosidase, $\alpha$-fucosidase, arginine dihydrolase, lysine decarboxylase or ornithine decarboxylase. Weak activity is observed for esterase (C4), esterase lipase (C8), valine arylamidase, acid phosphatase, naphthol-AS-BI-phosphohydrolase and tryptophan deamidase.

The type strain is $\mathrm{EMB} 320^{\mathrm{T}}$ (=KCTC $12616^{\mathrm{T}}=\mathrm{DSM}$ $\left.17982^{\mathrm{T}}\right)$, isolated from activated sludge that performed EBPR.

\section{Acknowledgements}

These efforts were supported by grants from the MOST/KOSEF to the Environmental Biotechnology National Core Research Center (grant R15-2003-012-02002-0) and to the 21C Frontier Microbial Genomics and Application Center Program (grant MG05-0104-4-0), Ministry of Science \& Technology, Korea. S.H.R., M.P. and Q.W. were supported by scholarships from the BK21 program, the Ministry of Education and Human Resources Development in Korea.

\section{References}

Blümel, S., Busse, H.-J., Stolz, A. \& Kämpfer, P. (2001). Xenophilus azovorans gen. nov., sp. nov., a soil bacterium that is able to degrade azo dyes of the Orange II type. Int J Syst Evol Microbiol 51, 1831-1837.

Busse, H.-J. \& Auling, G. (1988). Polyamine pattern as a chemotaxonomic marker within the Proteobacteria. Syst Appl Microbiol 11, 1-8.

Busse, H.-J., Bunka, S., Hensel, A. \& Lubitz, W. (1997). Discrimination of members of the family Pasteurellaceae based on polyamine patterns. Int J Syst Bacteriol 47, 698-708.

Cole, J. R., Chai, B., Marsh, T. L., Farris, R. J., Wang, Q., Kulam, S. A., Chandra, S., McGarrell, D. M., Schmidt, T. M. \& other authors (2003). The Ribosomal Database Project (RDP-II): previewing a new autoaligner that allows regular updates and the new prokaryotic taxonomy. Nucleic Acids Res 31, 442-443.

Ding, L. \& Yokota, A. (2004). Proposals of Curvibacter gracilis gen. nov., sp. nov. and Herbaspirillum putei sp. nov. for bacterial strains isolated from well water and reclassification of [Pseudomonas] huttiensis, [Pseudomonas] lanceolata, [Aquaspirillum] delicatum and 
[Aquaspirillum] autotrophicum as Herbaspirillum huttiense comb. nov., Curvibacter lanceolatus comb. nov., Curvibacter delicatus comb. nov. and Herbaspirillum autotrophicum comb. nov. Int J Syst Evol Microbiol 54, 2223-2230.

Felsenstein, J. (2002). PHYLIP (phylogeny inference package), version 3.6a. Distributed by the author. Department of Genetics, University of Washington, Seattle, USA.

Finneran, K. T., Johnsen, C. V. \& Lovley, D. R. (2003). Rhodoferax ferrireducens sp. nov., a psychrotolerant, facultatively anaerobic bacterium that oxidizes acetate with the reduction of $\mathrm{Fe}$ (III). Int J Syst Evol Microbiol 53, 669-673.

Gomori, G. (1955). Preparation of buffers for use in enzyme studies. Methods Enzymol 1, 138-146.

Heulin, T., Barakat, M., Christen, R., Lesourd, M., Sutra, L., De Luca, G. \& Achouak, W. (2003). Ramlibacter tataouinensis gen. nov., sp. nov., and Ramlibacter henchirensis sp. nov., cyst-producing bacteria isolated from subdesert soil in Tunisia. Int J Syst Evol Microbiol 53, 589-594.

Hiraishi, A. (1994). Phylogenetic affiliations of Rhodoferax fermentans and related species of phototrophic bacteria as determined by automated 16S rDNA sequencing. Curr Microbiol 28, 25-29.

Hiraishi, A., Hoshino, Y. \& Satoh, T. (1991). Rhodoferax fermentans gen. nov., sp. nov., a phototrophic purple nonsulfur bacterium previously referred to as the "Rhodocyclus gelatinosus-like" group. Arch Microbiol 155, 330-336.

Irgens, R. L., Gosink, J. J. \& Staley, J. T. (1996). Polaromonas vacuolata gen. nov., sp. nov., a psychrophilic, marine, gas vacuolate bacterium from Antarctica. Int J Syst Bacteriol 46, 822-826.

Jeon, C. O., Lee, D. S. \& Park, J. M. (2003). Microbial communities in activated sludge performing enhanced biological phosphorus removal in a sequencing batch reactor. Water Res 37, 2195-2205.

Jeon, C. O., Park, W., Ghiorse, W. C. \& Madsen, E. L. (2004). Polaromonas naphthalenivorans sp. nov., a naphthalene-degrading bacterium from naphthalene-contaminated sediment. Int J Syst Evol Microbiol 54, 93-97.

Jeon, C. O., Lim, J. M., Lee, J. M., Xu, L. H., Jiang, C. L. \& Kim, C. J. (2005). Reclassification of Bacillus haloalkaliphilus Fritze 1996 as Alkalibacillus haloalkaliphilus gen. nov., comb. nov. and the description of Alkalibacillus salilacus sp. nov., a novel halophilic bacterium isolated from a salt lake in China. Int J Syst Evol Microbiol 55, 1891-1896.

Kämpfer, P., Steiof, M. \& Dott, W. (1991). Microbiological characterization of a fuel-oil contaminated site including numerical identification of heterotrophic water and soil bacteria. Microb Ecol 21, 227-251.

Kämpfer, P., Busse, H.-J. \& Falsen, E. (2006). Polaromonas aquatica sp. nov., isolated from tap water. Int J Syst Evol Microbiol 56, 605-608.

Kimura, M. (1980). A simple method for estimating evolutionary rates of base substitutions through comparative studies of nucleotide sequences. J Mol Evol 16, 111-120.

Komagata, K. \& Suzuki, K. (1987). Lipid and cell-wall analysis in bacterial systematics. Methods Microbiol 19, 161-207.

Lane, D. J. (1991). 16S/23S rRNA sequencing. In Nucleic Acid Techniques in Bacterial Systematics, pp. 115-175. Edited by E. Stackebrandt \& M. Goodfellow. Chichester: Wiley.

Lányí, B. (1987). Classical and rapid identification methods for medically important bacteria. Methods Microbiol 19, 1-67.

Leifson, E. (1963). Determination of carbohydrate metabolism of marine bacteria. J Bacteriol 85, 1183-1184.
Lu, S., Park, M., Ro, H.-S., Lee, D. S., Park, W. \& Jeon, C. O. (2006). Analysis of microbial communities using culture-dependent and -independent approaches in an anaerobic/aerobic SBR reactor. J Microbiol 44, 155-161.

Malik, K. A. \& Schlegel, H. G. (1981). Chemolithoautotrophic growth of bacteria able to grow under $\mathrm{N}_{2}$-fixing conditions. FEMS Microbiol Lett 11, 63-67.

Mechichi, T., Stackebrandt, E. \& Fuchs, G. (2003). Alicycliphilus denitrificans gen. nov., sp. nov., a cyclohexanol-degrading, nitratereducing $\beta$-proteobacterium. Int J Syst Evol Microbiol 53, 147-152.

Sizova, M. \& Panikov, N. (2007). Polaromonas hydrogenivorans sp. nov., a psychrotolerant hydrogen-oxidizing bacterium from Alaskan soil. Int J Syst Evol Microbiol 57, 616-619.

Smibert, R. M. \& Krieg, N. R. (1994). Phenotypic characterization. In Methods for General and Molecular Bacteriology, pp. 607-654. Edited by P. Gerhardt, R. G. E. Murray, W. A. Wood \& N. R. Krieg. Washington, DC: American Society for Microbiology.

Spring, S., Jäckel, U., Wagner, M. \& Kämpfer, P. (2004). Ottowia thiooxydans gen. nov., sp. nov., a novel facultatively anaerobic, $\mathrm{N}_{2} \mathrm{O}$ producing bacterium isolated from activated sludge, and transfer of Aquaspirillum gracile to Hylemonella gracilis gen. nov., comb. nov. Int J Syst Evol Microbiol 54, 99-106.

Stackebrandt, E., Murray, R. G. E. \& Trüper, H. G. (1988). Proteobacteria classis nov., a name for the phylogenetic taxon that includes the "purple bacteria and their relatives". Int J Syst Bacteriol 38, 321-325.

Tamaoka, J. \& Komagata, K. (1984). Determination of DNA base composition by reversed-phase high-performance liquid chromatography. FEMS Microbiol Lett 25, 125-128.

Thompson, J. D., Higgins, D. G. \& Gibson, T. J. (1994). CLUSTAL W: improving the sensitivity of progressive multiple sequence alignment through sequence weighting, position-specific gap penalties and weight matrix choice. Nucleic Acids Res 22, 4673-4680.

Wang, Q., Garrity, G. M., Tiedje, J. M. \& Cole, J. R. (2007). Naïve Bayesian classifier for rapid assignment of rRNA sequences into the new bacterial taxonomy. Appl Environ Microbiol 73, 5261-5267.

Wen, A., Fegan, M., Hayward, C., Chakraborty, S. \& Sly, L. I. (1999). Phylogenetic relationships among members of the Comamonadaceae, and description of Delftia acidovorans (den Dooren de Jong 1926 and Tamaoka et al. 1987) gen. nov., comb. nov. Int J Syst Bacteriol 49, 567-576.

Willems, A., Gillis, M., Kersters, K., Van Den Broecke, L. \& De Ley, J. (1987). Transfer of Xanthomonas ampelina Panagopoulos 1969 to a new genus, Xylophilus gen. nov., as Xylophilus ampelinus (Panagopoulos 1969) comb. nov. Int J Syst Bacteriol 37, 422-430.

Willems, A., De Ley, J., Gillis, M. \& Kersters, K. (1991). Comamonadaceae, a new family encompassing the acidovorans rRNA complex, including Variovorax paradoxus gen. nov., comb. nov., for Alcaligenes paradoxus (Davis) 1969. Int J Syst Bacteriol 41, 445-450.

Willems, A., Goor, M., Thielemans, S., Gillis, M., Kersters, K. \& De Ley, J. (1992). Transfer of several phytopathogenic Pseudomonas species to Acidovorax avenae subsp. avenae subsp. nov., comb. nov., Acidovorax avenae subsp. citrulli, Acidovorax avenae subsp. cattleyae, and Acidovorax konjaci. Int J Syst Bacteriol 42, 107-119.

Wolin, E. A., Wolin, M. J. \& Wolfe, R. S. (1963). Formation of methane by bacterial extracts. J Biol Chem 238, 2882-2886.

Yoon, J. H., Kang, S. J. \& Oh, T. K. (2006). Variovorax dokdonensis sp. nov., isolated from soil. Int J Syst Evol Microbiol 56, 811-814. 